\title{
EVALUATION OF GENOTYPE X YEAR INTERACTION IN EXTRA-EARLY MATURING MAIZE HYBRIDS IN A TYPICAL SOUTHERN GUINEA SAVANNAH ECOLOGY.
}

\author{
Bankole, F.A, Olaoye, G. and Adeyemo, E. \\ Department of Agronomy \\ University of Ilorin, PMB 1515, llorin, Nigeria. \\ Corresponding author's e-mail address: jadesolaoluwa@yahoo.com.
}

\begin{abstract}
In Nigeria, genotype by environment interaction effect on maize grain yield is usually significant due to considerable variation in soil and weather conditions of the growing sites. This also complicates identification and selection of superior genotypes in a particular environment. Consequently a proper understanding of the effects of $G \times E$ interactions on varietal evaluation and cultivar recommendations is vital. This study was therefore conducted to evaluate performance of drought tolerant maize hybrids of different maturity groups. The first group comprised twenty-four extraearly yellow and the second comprised seventeen early white QPM hybrids, both obtained from the International Institute of Tropical Agriculture (IITA), Ibadan. The genetic materials were evaluated in replicated trials during the 2012 and 2013 growing seasons at the Teaching and Research Farm, University of Ilorin, in a typical Southern Guinea Savanna ecology of Nigeria. The effects of genotype $(G)$, year $(Y)$ and $G \times Y$ were found to be highly significant $(P<0.01)$ for grain yield in the extra-early yellow hybrids (EEYH) while among the early white QPM hybrids, genotypic (G) effect was significant only for days to silk and plant height. $G \times Y$ interactive effect was however significant only for days to silking. Hybrids EEYH-5, EEYH-27 and EWQH-3 were consistent among the top 5 ranking genotypes for both years in terms of grain yield, an indication for stability to this ecology. Correlation between grain yield and associated traits showed that ears per plant and plant height contributed significantly to grain yield in both groups. Regression analysis of grain yield and other associated traits also revealed that ears per plant contributed significantly to grain yield in extra early yellow hybrids while plant height contributed significantly in the early white QPM hybrids. Therefore, selection programme should give attention to ears per plant and plant height in the varieties intended for drought prone ecology of the Southern Guinea Savanna of Nigeria.
\end{abstract}

Key words: Genotype, Maize, Hybrids Early-maturing, Extral-early maturing

\section{INTRODUCTION}

The Savannah of West and Central Africa (WCA) has one of the greatest potential for maize production because of relatively higher incidence of solar radiation and lower incident of pest and 
diseases during the cropping season (Badu-Apraku et. al., 2006). Due to its nutrition importance in the livestock feed (Bolu and Ibikunle, 2009), maize production has been reported to occupy large expanse of land (Bibinu et al., 2006). However, moisture deficit conditions due to irregular rainfall pattern, mid-season and/or terminal drought which is accentuated by poor soil water holding capacity often limit maize yields in the zone (Olaoye and Omueti, 2006). The importance of maize in Nigeria and the Sub- Saharan Africa (SSA) necessitates focusing research efforts on enhancing the potential of new maize varieties (open pollinated and/or hybrids) through breeding and agronomic practices to increase productivity under a wide range of environmental conditions including moisture deficit situation. This is because growing of high yielding and stable maize varieties will help to increase maize production and lead to improved living standards of the resource limited farmers.

Extra-early (80-85 days) and early (90-95 days) maturing maize varieties have been reported to contribute to food security and increased incomes of farmers especially in marginal rainfall areas of the west and central Africa (IITA R4D Review, 2013). These groups of maize genotypes offer flexibility in planting dates which enables multiple plantings to spread the risk of crop failure due to delayed onset of rainfall, mid-season or terminal drought (Pswarayi and Vivek, 2007). Recent research activities at the International Institute of Tropical Agriculture (IITA), Ibadan, have also resulted in the release of genotypes within each maturity class, genotypes with genes for drought tolerance (DT) that enhance their capacity to tolerate moisture deficit conditions occurring during flowering and grain - filling periods; thereby making them suitable for cultivation in marginal rainfall areas and situations where terminal drought can occur (IITA R4D Review, 2013). However, the preliminary step in varietal release is to evaluate the genotypes for yield potential and adaptation to the environment where it is intended to be cultivated. According to Gurmu et al., (2009), breeders in most cases look for a variety that has good mean performances over a large array of environments and years without considering the concept of stability. This approach is suitable if there is no GE. However, in most cases, there is interaction between genotypes and the environments. The authors further explained that some genotypes may be high yielding in few environments but have very low yields in other environments, while showing better mean performance across environments. Stability of yield of a cultivar across large production environments is essential for variety recommendation. Such cultivars must show superior performances under ideal growing conditions, produce acceptable yields under ideal growing conditions and with acceptable yields under less favourable environments. Consequently, Allard and Bradshaw (1964) as well as Eberhart and Russell (1966)., defined a stable genotype as one that is capable of utilizing the resources available in high yielding environments with a mean performance that is above average in all environments. Finlay and Wilkinson (1963), earlier concluded that stability is a function of the regression coefficient while adaptability is a function of the mean yield of the variety.

The regression approach has been used to elucidate the nature of the relationship between genotypic performance and the prevailing environmental conditions and thus characterize the 
response of genotypes to wide range of environmental conditions. The regression approach includes analysis of variance followed by a joint regression (JR) analysis to determine whether or not the genotype and environment interaction (GEI) is a linear function of the environmental effects. According to Perkins et al., (1973), the use of the combined analysis of variance in the measuring of $\mathrm{GE}$, when the cultivars are evaluated at different environments, but fails to explain the differential responses of the individual cultivars to the various environments. The authors also noted that the magnitude of the GE is a linear function of the environmental effects.

The regression approach has been used by several authors to partition the components of GEI to predict genotypic performance in many crops. Anley et al., (2013) evaluated 15 genotypes at four different locations for stability and adaptability. Their results revealed a significant $G \times E$ indicating inconsistency in performance of genotypes across environments. Their results also showed that the sum of squares for location contributed the largest of all sources of variation. Based on JR model, $\mathrm{BH}-670$ had the lowest $s^{2} d_{i}$ value and regarded as the most stable while Phb-30H83 was the most unpredictable with the highest $s^{2} d_{i}$ value. When $b_{i}$ was considered, varieties 30D79 and Gibe -1 were the most stable while variety Wonchi was the most stable when the mean yield, $b_{i}$ and $s^{2} d_{i}$ were considered together.

Aremu et al., (2007) analysed 10 cowpea genotypes grown under four different environments, comprising 2 different locations in 2 consecutive years, and reported that the GE effects were significant for grain yield. Their results indicated that a large proportion of GE was nonlinear as revealed in the significant interaction of genotype and environment. They suggested the unreliability of JRA in selecting for high yield and stability of performance. The regression co-efficient, $b_{i}$, revealed that vars. IT97K - 499 - 39, TVX - 3236, AGRIBVI, Owode and Ife brown, irrespective of environment, would produce high yields. Var. IAR48B on the other hand was less consistent and would require nutrient supplementation to produce averagely. The authors further noted the effectiveness of regression co-efficient especially in multilocational GE studies, as it showed genotype performances in either good or bad environment. Furthermore, there was a positive correlation between regression co-efficient and grain yield of cowpea indicating that the genotypes were responsive to different environments. Other statistical methods like Si3, Pi statistics and Modified rank sum method can be interchangeable used as they all identified Owode, Ife - brown, TVX - 3236, IT97K - 499 - 39 to be the most desirable by combining high yield with consistent performance.

Afzal et al., (2011), assessed the performances and yield stability of nine (9) high yielding strains of wheat along with three (3) check varieties across diverse locations in two (2) consecutive years. Their results revealed a highly significant GE which explained the impact of environments in the expression of grain yields in the tested wheat genotypes. In the first year, var. MSH - 14 had the highest overall mean yield. A non significant increase in grain yield was observed in the check 
varieties. In the second year, vars. MSH - 03 and MSH -14 ranked $1^{\text {st }}$ and $3^{\text {rd }}$ respectively for yield. The stability analysis revealed that the high yielding genotype, (var. $\mathrm{MSH}-14$ ), had a regression co-efficient (bi), close to unity and deviation from regression $\left(\mathrm{s}^{2} \mathrm{~d}_{\mathrm{i}}\right.$, close to zero, indicating wide adaptation and stability of performance over environments. Genotypes MSH - 03 and MSH -05 had high yield but lower $b_{i}$ and higher $s^{2} d_{i}$ indicating specific adaptation to unfavourable environments and will do well as stress tolerant genotypes. Genotypes NIA - 4/7 had an above $b_{i}$ indicating adaptability to favourable conditions.

Shrestha (2013), studied six (6) varieties of quality protein maize across 11 locations for two (2) years to determine their stability and identify superior genotypes. Results from Combined ANOVA showed that the mean square due to the environment was highly significant while GEI was nonsignificant. Their results further showed that genotype S99TLYQ - B produced the highest yield on the average across locations and years. Genotypes S03 TLYQ - AB02 and Ranpur S03FQ02 on the other hand, were better adapted to favourable environments while genotype S99T TLYQ - B was more adapted to harsh environments. Genotype S03TLYQ -AB02 was the most suitable.

Gurmu et al., (2009), conducted an experiment involving 20 soybean genotypes evaluated at five (5) different locations to determine their yield, stability and adaptability. The authors reported a very high significant difference among genotypes for grain yield. When the total sums of squares was partitioned for yield, oil content and protein content, the environment component of both yield and oil content took the largest portion while GE took the largest portion in the case of protein content. Results from joint regression analysis revealed that none of the genotypes showed stability of performance for crude protein content but genotype Clark - 63k was the most adapted. Both genotypes $G-9945$ and Hardee -1 ranked $1^{\text {st }}$ and $2^{\text {nd }}$ in stability but could not be considered stable since they were the least yielding genotypes for crude protein content, very unstable and specifically adapted to a single location.

\section{MATERIALS AND METHODS}

\section{Source of Genetic Materials}

The genetic materials used for this study comprised eighteen (18) early white drought tolerant (DT) and twenty-four (24) extra-early yellow maize hybrids obtained from the International Institute of Tropical Agriculture (IITA), Ibadan. The hybrids were evaluated at the Teaching and Research (T\& R) farm, University of llorin in a typical Southern guinea Savannah (SGS) ecology of Nigeria ( $8^{\circ}$ $30 \mathrm{~N} ; 4^{\circ} 32 \mathrm{E}$ ) for two cropping seasons (2012 \& 2013). The lists of the varieties are presented in Table 1. Each set was planted as separate experiments, but beside each other in both years. The trials were laid in two-row plots in a randomized complete block (RCBD) with three replications, of 5 $\mathrm{m}$ long and at inter-row spacing of $75 \mathrm{~cm}$ and within row spacing of $40 \mathrm{~cm}$. Three seeds were initially 
planted per hill but were later thinned to two (2) stands/hill three (3) weeks after planting (WAP). The trials were conducted under rain-fed condition during the full growing seasons.

\section{Data Collection}

Data were collected on days to emergence count at seven (7) and nine (9) days after planting, days to anthesis and silking, plant and ear heights, and other ear characteristics husk cover, ear rot as well as field weight. Emergence count was taken by counting the number of plants that germinated at 7 and 9 days after planting respectively while days to anthesis and silking were recorded as the number of days from planting when $50 \%$ of plants in a plot have shed pollen and had silk extrusion respectively. Plant and ear heights were recorded in centimetres $(\mathrm{cm})$ from five random plants selected in a plot as distance from the ground level to the node bearing the flag leaf and the node bearing the uppermost ear from the same plants from which plant heights were recorded. Husk cover was rated on a scale of 1-5, where $1=$ husks tightly arranged and extended beyond the ear tip and $5=$ ear tips exposed while Ear rot was also rated on the scale of 1 to 5 , where $1=$ little or no visible ear rot and $5=$ extensive visible ear rot. Anthesis-silking-interval (ASI) was computed as the difference between days to anthesis and days to silking. The weight of ears harvested in a plot was first recorded in kilogrammes/plot and later converted to grain yield (t/ha) assuming shelling percentage of $80 \%$ and adjusted to $12 \%$ moisture content from readings obtained from the moisture meter. The formula used is as stated below:

GYLD/ha $=\left[\right.$ Field weight $\times(100-$ moisture $\%) \times 0.8(S) \times 10,000 \mathrm{~m}^{2} /$ ha $/(100-12) \times$ harvested area. Where $\mathrm{S}=$ Shelling percentage $(\%)$.

\section{Data Analysis}

Data collected and estimated were first subjected to individual analyses of variance (ANOVA) based on years followed by a combined ANOVA across years for each set of hybrids. Pertinent means were thereafter separated using the least significant difference (LSD) at 0.05 probability level (Steel and Torrie, 1980). Further analysis was performed by subjecting the data to Regression analysis using the model.

\section{RESULTS AND DISCUSSION}

The results of the mean squares from the combined analysis of variance (AOV) for grain yield and related traits for the Early QPM white hybrids are presented in Table 2. The two years had a significant effect $(P<0.01)$ only on plant height and ears per plant while differences among the hybrids $(G)$ was significant $(P<0.05$ or $<0.01)$ days to flowering, plant height and grain yield. This implies that the genotypes differed significantly from one another for these traits, which corroborates to earlier reports from previous studies (Olaoye and Omueti, 2006; Gurmu et al., 2009; Adebo et al., (2010). The interactive effects of $G$ x Y was significant only for days to silking.

Among the extra-early yellow hybrids Climatic factors in the two years $(Y)$ had a pronounced effect only on the expression of all the traits (Table 3). However, the genotypes as well as the interactive 
effects of $G \times Y$ were significant for plant height, ears per plant and grain yield respectively. This suggests differential performance of the genotypes in this maturity group in each year of evaluation for these traits, probably in response to the differences in climatic factors in the two years of study. Significant G x Y for grain yield has also been reported in several studies (Aremu et al., 2007; Afzal et al., 2011; Anley et al., 2013). However, all the traits were significantly affected by the difference in the factors of the environment in each year.

Means of grain yield and other related components in 17 Early White QPM Hybrids (Table 4) revealed a significant difference for grain yield and plant height among the hybrids, with EWQH-3 recording the highest yielding with about 125\% yield advantage over EWQH-2 which was the lowest yielding hybrid in this group. Height of the plants appeared to influence grain yield as genotypes such as EWQH -3, EWQH -8 and EWQH -13 with high mean grain yield were also significantly taller than low yielding genotypes such as EWQH-2 and EWQH-6. This observation which is similar to earlier report of Bello et al., (2009) implies the existence of a positive correlation between grain yield and plant height.

Means of grain yield and other related components in 24 Extra-Early Yellow Hybrids showed that EEYH-5 was the highest yielding hybrid with about 140\% advantage over EEYH-24 which was the lowest yielding hybrid (Table 4). Furthermore, the hybrids that were high yielding also had higher ear placement and higher number of ears per plant relative to the low yielding hybrids (for example, EEYH -7 and EEYH -8) which was similar to the earlier report of Monneveux et al., (2006).

The results of the Interactive effects of $G \times Y$ on grain yield in the 24 Extra-Early Yellow Hybrids(Table 5) showed that all the genotypes had better performance for grain yield in 2012 compared to 2013. This may be due to the prolonged moisture stress which occurred during the growing season of 2013 at the T \& R farm, llorin. Hybrids EEYH-5 and EEYH-27 ranked among the high yielding genotypes in both years with respect to grain yield suggesting relative stability of performance. The two hybrids differed by more than 2.7 and 2.6 tons respectively in favour of the 2012 growing season thereby emphasizing the effects of environmental factors, especially moisture stress, on grain yield. Hybrid EEYH-24 was the lowest yielding genotypes in both years.

The nature of association between grain yield and related traits in the two groups of hybrids are presented in Table 6. Among the early white QPM hybrids, ears per plant and plant height correlated positively with grain yield in both years while anthesis-silking-interval correlated positively with the same trait only in 2013 when there was prolonged moisture stress. Similar to the nature association in early white QPM hybrids, ears per plant correlated positively with grain yield in both years in the extra-early yellow hybrids. However, plant height correlated positively with grain yield only in 2012 cropping season. The positive correlation between ears per plant and grain yield is expected because it is one of the primary determinants of grain yield in maize especially under moisture deficit condition. Although days to silk had a negative association with grain yield (as expected), the 
association was non-significant. Previous studies have shown a positive correlation of ears per plant and plant height with grain yield and a negative correlation of days to silking with grain yield. (Bello et al., 2009; Ngugi et al., 2013).

Regression of grain yield on yield related components (Table 7) revealed that plant height was the only trait that contributed significantly to grain yield $(P<0.05)$ in the early white QPM hybrids. The coefficient of determination showed that $25.5 \%$ of the variation in grain yield was explained through plant height and ears per plant respectively. Conversely, ears per plant was the trait that contributed significantly to grain yield in the extra early yellow hybrids with coefficient of determination of $>75 \%$. Though, anthesis-silking-interval had a positive regression coefficient, its contribution was relatively negligible. Plant height had a negative regression coefficient against grain yield in this population probably because tall plants are usually prone to lodging which will reduce grain yield significantly.

The scatter plots of grain yield against related traits in the 17 early white QPM hybrids are presented in Figs. 1a-c. With respect to anthesis-silking-interval, the high yielding hybrids were clustered at the upper part of the line (Fig. 1a) while there was an upward movement of the grain yield as plant height increased. Hybrids at the plant height extremes were low yielding while those that yielded high were moderately tall (Fig.1b). This corroborates earlier observations on the relationship between plant height and grain yield (Table 6). A similar relationship like anthesis-silking-interval existed between ears per plant and grain yield (Fig. 1c) as revealed by an upward movement of grain yield as ears per plant increased.

The scatter plots of grain yield against related traits in the 24 extra-early yellow hybrids (Figs 2a-c) also revealed an upward relationship between grain yield and anthesis silking interval (Fig. 2a) while there was a declining relationship between grain yield and plant height (Fig. 2b). It was also observed that the hybrids with high grain yield were moderately tall. A steep upward movement of grain yield with a corresponding increase in ears per plant (Fig. 2c) showed that the high yielding hybrids were those that produced high number of ears per plant.

\section{General Discussion}

In this study, the expression of all the traits investigated was significantly affected by the factors of the environment in each year, particularly rainfall amount and distribution. For example, the genotypes attained days to silking faster in 2012 by 20 days compared to 2013. Consequently, grain yield was higher by more than 1.5 tons/ha in 2012. Anthesis-silking-interval for the genotypes in 2012 was also shorter by two (2) days than value obtained in 2013 (i.e. 4 days). Short anthesissilking interval ensures good nicking between pollen shed and silking which was probably responsible for the high grain yield in 2012. These attributes are desired in breeding for drought tolerance and have been shown by several studies to contribute significantly to increase in grain yield. (Banziger et al., 2000, Monneveux et al., 2006; Bello et al., 2009; Ngugi et al., 
2013).Therefore, it can be deduced that performances of the individual hybrids were better in 2012 compared to those of 2013 , which was probably due to the prolonged moisture stress experienced in 2013.

Hybrids EEYH-5, EEYH-27 among the extra early yellow hybrids and EWQH-3 from the early white QPM hybrid maintained consistency of performance with respect to grain yield in both years. Hence, these hybrids can be further tested in large plot size to validate their performance for grain yield. Furthermore, hybrid EEYH-5 which was superior for grain yield and also exhibit stability of performance for grain yield in the two years can be evaluated on farmers' fields for possible release. The extra early varieties should be given special attention since they can be cultivated in short period of rainy season in this ecology.

\section{REFERENCES}

Afzal Arain, M., M. Ali Sial, M. Arif Rajput, A. A. Mirbahar.(2011). Yield Stability in Bread Wheat Genotypes.Pak. J. Bot., 43(4): 2071-2074.

Akçura, M., S. Taner and Y. Kaya (2011).Evaluation of Bread Wheat Genotypes under Irrigated Multi-environment Conditions using GGE BiplotAnalyses.Agriculture, 98(1), 35-40.

Allard, R.W. and A.D. Bradshaw, 1964.Implications of Genotype-environment Interactions in Applied Plant Breeding.Crop Sci., 4: 503-508.

Anley, W., H. Zeleke, and Y. Dessalegn.(2013). Genotype X Environment Interaction of Maize (Zea mays L.) across North Western Ethiopia. J. Plant Breed.Crop Sci.pp. 171-181.

Annapurna, D., H. A. Khan. and S. Mohammad. 1998. Genotypic-Phenotypic Correlations and Path Coefficient Analysis between seed yield and other Associated Characters in all Genotypes of Maize. Crop Res. Hisar. 16:205-9.

Aremu, C.O., O. J. Ariyo and B. D. Adewale, (2007).Assessment of Selection Techniques in Genotype $x$ Environment Interaction in Cowpea, Vigna unguiculata (L.) walp.Afr. J. Agric. Res. Vol. 2(8), pp. 352-355.

Badu-Apraku, B., A. Menkir, M.A.B. Fakorede, A. Fonten Lum, and K. Obeng-Antwi (2006) Multivariate analyses of the genetic diversity of forty-seven Striga resistant tropical early maturing maize inbred lines. Maydica 51:551-559

Baker, H.C. and J.Leon. 1988. Stability analysis in plant breeding. Plant Breeding, 101: 11-23.

Banziger, M., G. O. Edmeades, D. Beck, \& M. Bellon, (2000).Breeding for drought and nitrogenstress tolerance in maize.From theory to practice. Mexico, D.F., CIMMYT. pp 2329.

Bello, O. B., S. Y. Abbdulmaliq, M. S. Afolabi and S. A. Ige, (2009).Correlation and path coefficient analysis of imperative selection on the developing variety of maize.African Journal of Biotechnology Vol. 9 (18), pp. 2633-2639 
Bibinu A. T. S., Isa A. and Bwatanglang N.K. (2006) Sorghum/Millet Mixture as Affected by Crop Proportion and Sorghum Cultivar in A Semi-Arid Environment. Agrosearch Journal Vol 10 (1\&2): $89-97$

Boakyewaa, G.A. (2012). Genotype by environment interaction and grain yield stability of extra early maize (Zea mays L.) hybrids evaluated at three locations in Ghana. M.Sc Thesis. Kwame Nkrumah University of Science and Technology, Ghana.

Bolu, S.A. And Ibikunle, M (2009).Alternative/Conventional Feedstuff in Broiler Production in Nigeria. Agrosearch Journal Vol 10(1\&2): 55-63

Boyer, C.D., L. C. Hannah, (1994).Kernel mutants of corn.Chapter 1. In: AR Hallauer, ed. Specialty corns. CRC PressInc Boca Raton, USA. pp 1-28.

CiXiao-ke, S. H. Zhang, Z. J. Xie, J. S. Xu , Z. Y. Lu, G. L. Ru, D. G. Zhang, X. H. Li, C. X. Xie, L. B a i, M. S. Li, S. T. Dong, (2010). Comparison of analysis method of genetic yield gain for the single-cross hybrids released during 1970s-2000s. Acta Agron.Sin., 36(12): 2185 2190.

Eberhart S., W. Russell (1966). Stability parameters for comparing varieties. Crop Sci. 6: 36-40.

Erenstein, O. (2010). The evolving maize sector in Asia: challenges and opportunities. Journal of New Seeds 11: 1-15.

FAO Food Outlook, (2006).http://www.fao.org/docrep/009/J7927e/j7927e03.htm\#32.

FAO Report (2010). $h$ ttp://www.fao.org/docrep/013/i1683e/i1683e.pdf

Farnham, D.E., Benson, G.O., Pearce, R.B. (2003). Corn perspective and culture.Chapter 1. In: PJ White, LA Johnson, eds. Corn: chemistry and technology, Edition 2nd. American Association of Cerial Chemicals, Inc. St. Paul, Minesota, USA.pp 1-33.

Fehr, W. R (1991).Principles of cultivar development.Theory and technique.Mac Millan Publishing Co., 1:536.

Finlay, K.W., and G. N. Wilkinson. 1963. The analysis of adaptation in a plant breeding programme. Aust. J. Agri. Res. 14: 742754.

Frova, C. and G. Binelli, (1988) HSPs: more data on genetic variability. MNL62:94

Gauch, H.G. and Zobel, R.W., 1997. Identifying mega-environments and targeting genotypes. Crop Sci37(2): 311-326.

Golbashy M, M. Ebrahimi, S. Khorasani, R. Choukan (2010). Evaluation of drought tolerance of some corn (Zea mays L.) hybrids in Iran.Afr. J. Agric. Res., 5(19): 2714-2719.

Gurmu, F., H. Mohammed and G. Mewmaw, (2009).Genotype x Environment Interactions and Stability of Soybean for grain yield and Nutrition quality. African Crop Science Journal, Vol. 17, No. 2, pp. $87-97$.

Hill, J., H. C. Becker, and P. M. A. Tigerstedt, (1997).Quantitative and ecological aspects of plant breeding (pp. 50-1, 89-102 and155-173). London: Chapman and Hall.

Hobbs, L. (2003). Corn sweeteners.Chapter 17. In: PJ White, LA Johnson, eds. Corn: chemistry and technology, Edition 2. American Association of Cerial Chemicals, Inc. St. Paul, Minesota, USA. pp 635-669. 
IITA R4D Review (2013).http://r4dreview.org/2013/07/two-extra-early-maturing-white-maize hybrids-released-in-nigeria/

Ngugi, K., J. Cheserek , C. Muchira and G. Chemining'wa, (2013). Anthesis to Silking Interval Usefulness in Developing Drought Tolerant Maize. Journal of Renewable Agriculture(2013) 84-90

Kang, M.S., (1996). Using genotype-by-environment interaction for crop cultivar development. Advances in Agronomy 62: 199-252.

Li S.K, C.T Wang (2009). Evolution and development of maize production techniques in China. Sci. Agric Sin., 42(6): 1941-1951.

Machuka, J. R. Oduor, S. Runo, R. Adam, J. Matheka,L. Bedada, M. Seth, E. Kuria, C. Masiga and C. Mugoya, (2011). Genetic engineering of maize for drought tolerance in Eastern and Central Africa. http://www.asareca.org/resources/reports/GeneticengineeringofMaize.pdf

Malosetti, M., J. M. Ribaut, M. Vargas, J. Crossa, M. P. Boer, and F. A. Van Eewijk, (2007). Multitrait multi - environment QTL modelling for drought - stress adaptation in maize. Scale and Complexity in Plant Systems Research: Gene-Plant-Crop Relations,25-36.

Matsuoka, Y., Y. Vigouroux, M. M. Goodman, G. J. Sanchez, E. Buckler, J. Doebley, (2002). A single domestication for maize shown by multilocus microsatellite genotyping. Proceedings of the NationalAcademy of Sciences 99: 6080-6084.

McCutcheon, A. (2007). Victoria, Australia, Agriculture Notes - Bioethanol in Victoria. AG1314, 13 State of Victoria, Department of Primary Industries, available online at http://www.dpi.vic.gov.au/dpi/nreninf.nsf/v/FDD7771DC12D8B47CA25740900829BDB/\$ fil IAG1314_Sep07.pdf Agriculture Notes.

Monneveux, P., E. Belhassen, (1996).The diversity of drought adaptation in the wild, Plant Growth Regul. 20(1996) 85-92

Monneveux, P., C. Sánchez, D. Beck, and G.O. Edmeades, (2006). Drought tolerance improvement in tropical maize source populations: evidence of progress. Crop Science $46,180-191$.

Negeve, J. M. (1993). Regression analysis of genotype x environment interaction in sweet potato. Euphytica., 71:231-238.

Paliwal, R.L. (2000a). Genetic Resources. In: R. L. Paliwal, G. Granados, H. R. Lafitte, A. D. Vlollc, eds. Tropical Maize: Improvement and Production. Food and Agriculture Organization of the United Nations Rome. pp 105-114.

Paliwal, R.L. (2000b). Introduction to maize and its importance. Chapter 1. In: Tropical Maize: Improvement and Production. Food and Agriculture Organization of the United Nations Rome.pp 1-3.

Paliwal, R.L. (2000g). Uses of Maize. In: R. L. Paliwal, G. Granados, H. R. Lafitte,A. D. Vlollc, eds. Tropical Maize: Improvement and Production. Food and Agriculture Organization of $\mathrm{t} h \mathrm{~h}$ United Nations Rome.pp 45-57. 
Paliwal, R.L. (2000h). Uses of maize.Chapter 7. In: RL Paliwal, G Granados, HR Lafitte, AD Vlollc, eds. Tropical Maize: Improvement and Production. Food and Agriculture Organization of the United Nations Rome. pp 45-57.

Perkins, J. M. and J. L. Jinks, (1973).The assessment and specificity of environmental components of variability. Heridity, 30: 111-126

Piperno, D.R., K. V. Flannery, (2001). The earliest archaeological maize (Zea mays L.) from highland Mexico: New accelerator mass spectrometry dates and their implications. Proceedings of the NationalAcademy of Sciences98: 2101-2103

Pswarayi, A. and B. S. Vivek, (2007). Combining ability amongst CIMMYT's early maturing maize (Zea mays L.) germplasm under stress and non-stress conditions and identification of testers. Eupytica.162: 353-362.

Rafiq, C. M., M. Rafique, A. Hussain, M. Altaf (2010). Studies on heritability, correlation and path analysis in maize (Zea mays L.).J. Agric. Res., 48(1): 35-38.

Rohrbach, D.D., 1998. Assessing the impact of entomology research. In: Proceeding of the workshop on management of sorghum and pearl millet pests in the SADC region of 1998.Matopos Research Station, Zimbabwe pp. 95-103.

Shrestha, J., (2013), Genotype by Environment Interaction and Yield Stability Analysis of Quality Protein Maize genotypes in Terai region of Nepal. Int. J. Appl. Sci. Biotechnol, Vol. 1(2): $74-78$.

Sibiya, J., P. Tongoona, J. Derera, and N. Rij, (2012).Genetic analysis and genotype by environment ( $G X E$ ) for grey leaf spot disease resistance in elite African maize (Zea mays L.) germplasm. Euphytica, 185, 349-362.

Steel, R. G. D., J. H. Torrie, (1980).Principles and Procedure of Statistics.McGraw Hill Book Inc. New York. pg. 580.

Tuberosa, R., E. Frascaroli, S. Salvi, M. C. Sangauineti, S. Conti, and P. Landi, (2005). QTLS for tolerance to abiotic stresses in maize: present status and prospects. Maydica 50:559569

White, P.J. (1994). Properties of corn starch. Chapter 2. In: AR Hallauer, ed. Specialty corns. CRC Press Inc Boca Raton, USA. pp 29-54.

Wikipedia. http://en.wikipedia.org/wiki/Maize

Yates, F. \& W.G. Cochran (1938). The analysis of groups of experiments. Journal of Agricultural Sci., 28:556-580.

Zhang, S. H., Z. G. Xu, (2009). Cultivar system changes and its effect on agricultural Technique. Crop Sci. 25(1): 1-3. 
Table 1: List of the Genetic Materials used in the study

\begin{tabular}{llll}
\hline S/N & Extra-Early Yellow Hybrids & S/N & Early White QPM Hybrids \\
\hline 1. & EEYH-3 & 1. & EWQH-1 \\
2. & EEYH-4 & 2. & EWQH-2 \\
3. & EEYH-5 & 3. & EWQH-3 \\
4. & EEYH-6 & 4. & EWQH-4 \\
5. & EEYH-7 & 5. & EWQH-5 \\
6. & EEYH-8 & 6. & EWQH-6 \\
7. & EEYH-11 & 7. & EWQH-7 \\
8. & EEYH-13 & 8. & EWQH-8 \\
9. & EEYH-25 & 9. & EWQH-9 \\
10. & EEYH-15 & 10. & EWQH-10 \\
11. & EEYH-16 & 11. & EWQH-11 \\
12. & EEYH-17 & 12. & EWQH-12 \\
13. & EEYH-18 & 13. & EWQH-13 \\
14. & EEYH-19 & 14. & EWQH-14 \\
15. & EEYH-20 & 15. & EWQH-15 \\
16. & EEYH-21 & 16. & EWQH-17 \\
17. & EEYH-23 & 17. & EWQH-18 \\
18. & EEYH-24 & 18. & EWQH-19 \\
19. & EEYH-26 & & \\
20. & EEYH-27 & & \\
21. & EEYH-28 & & \\
22. & EEYH-29 & & \\
23. & EEYH-30 & & \\
24. & EEYH 32 & & \\
\hline
\end{tabular}




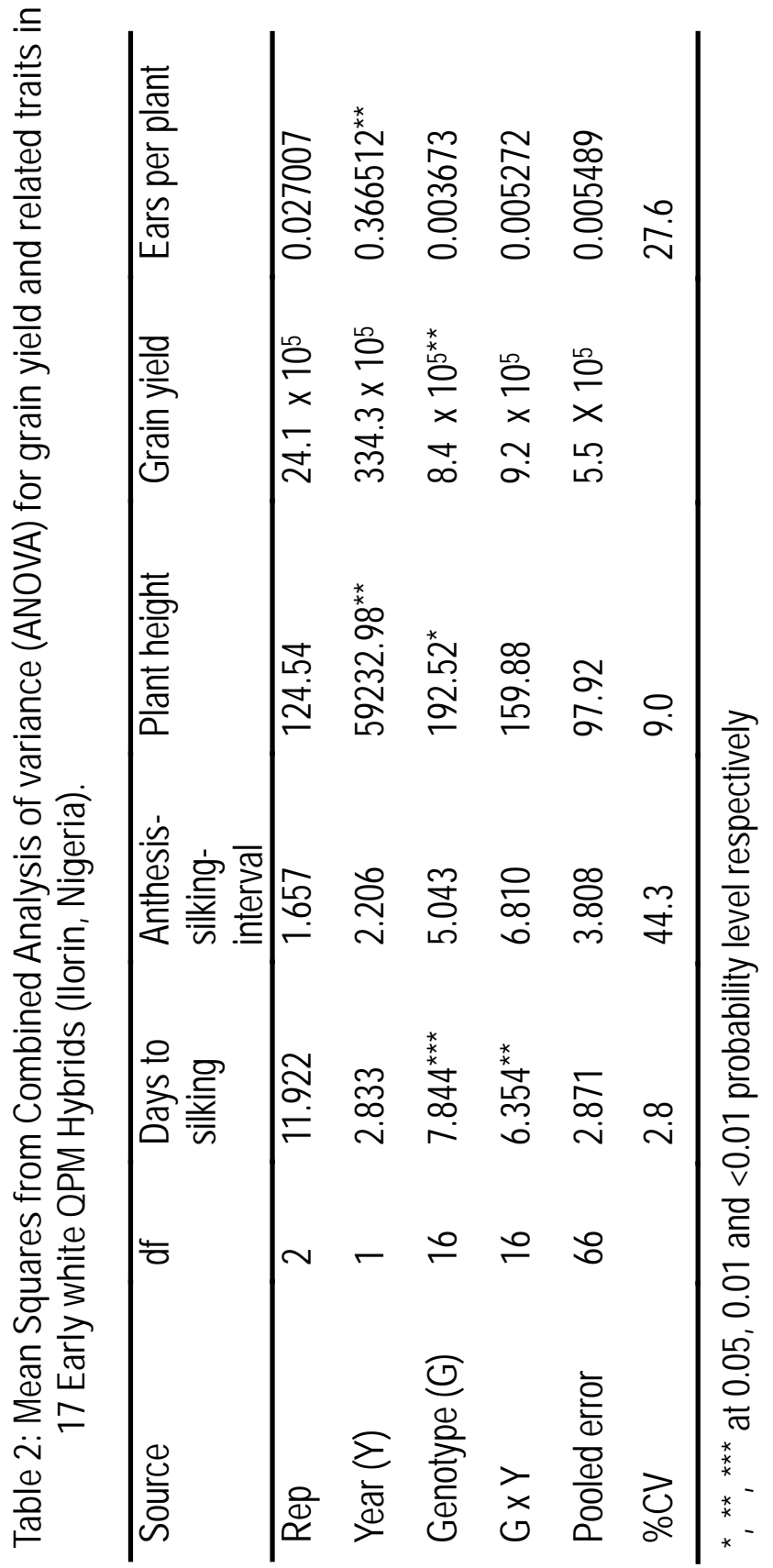


Bankole. Olaoye \& Adeyemo

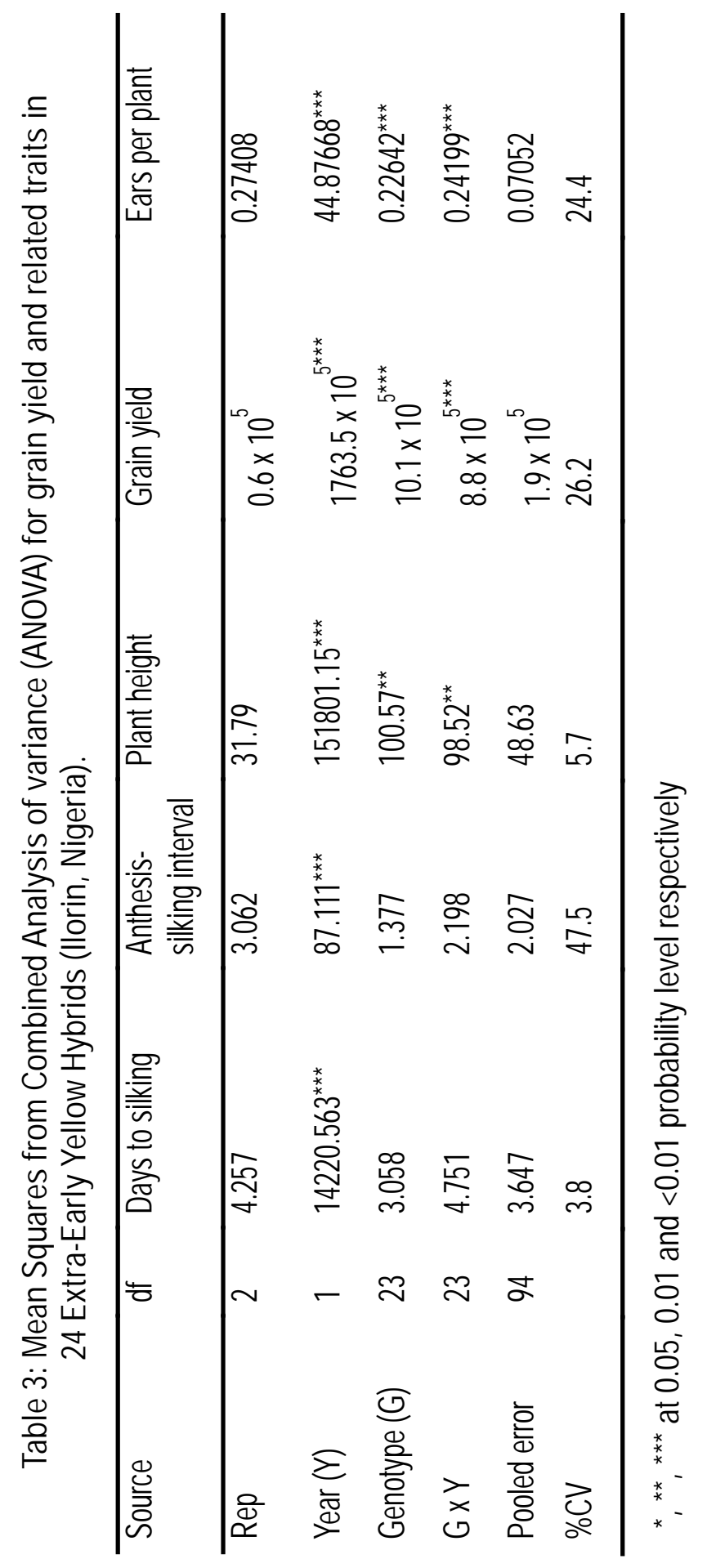


Bankole. Olaoye \& Adeyemo

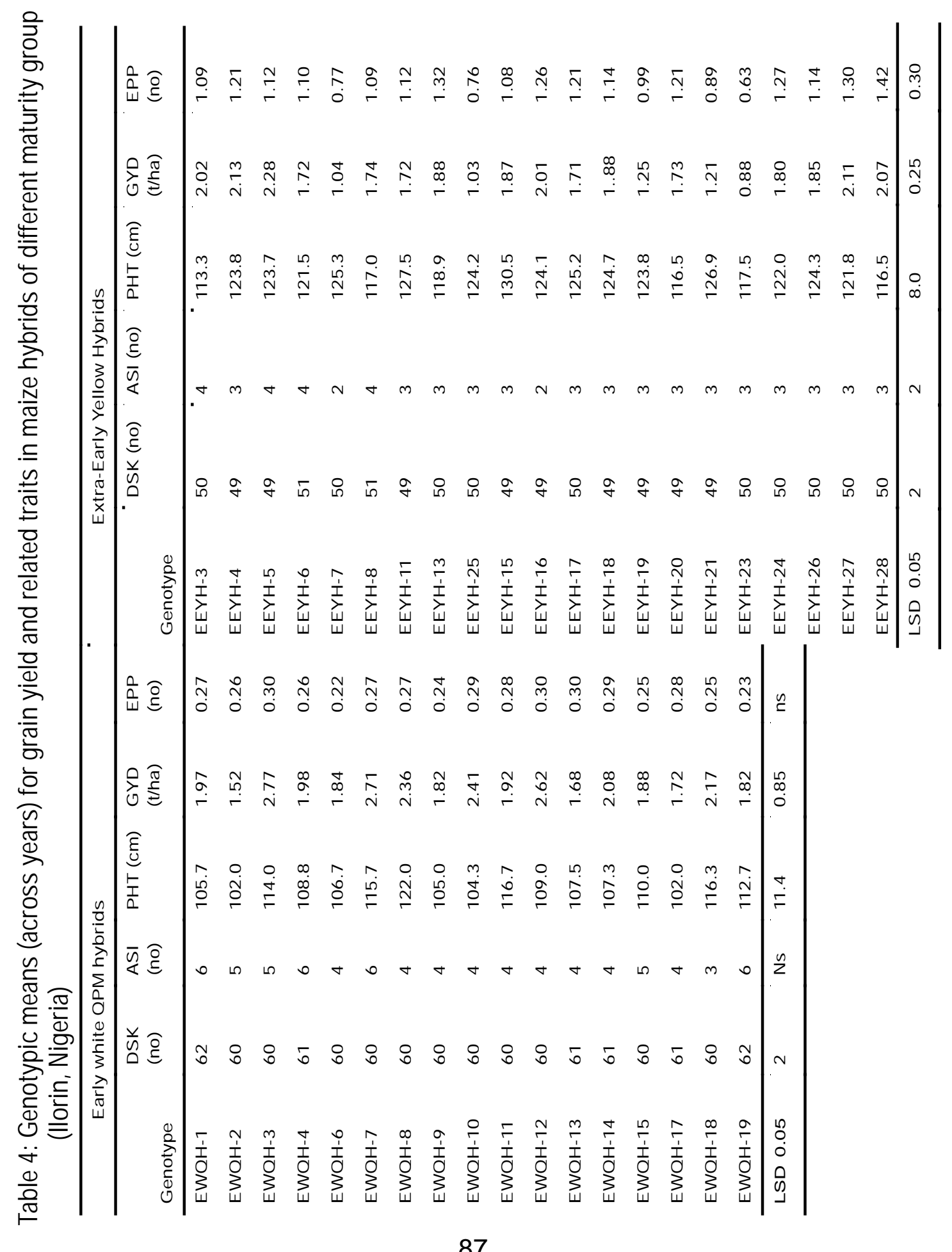


Table 5: Interactive effects of genotype $x$ environment on grain yield (kg/ha) in 24 Extra-Early Yellow Hybrids (llorin, Nigeria)

\begin{tabular}{lllll}
\hline S/N & Genotype & Year & & Mean \\
\hline & & 2012 & 2013 & \\
\hline 1 & EEYH-3 & 3610 & 419 & 2015 \\
2 & EEYH-4 & 3606 & 648 & 2127 \\
3 & EEYH-5 & 3679 & 883 & 2281 \\
4 & EEYH-6 & 3056 & 389 & 1722 \\
5 & EEYH-7 & 1754 & 325 & 1040 \\
6 & EEYH-8 & 3154 & 326 & 1740 \\
7 & EEYH-11 & 3155 & 292 & 1723 \\
8 & EEYH-13 & 2996 & 755 & 1875 \\
9 & EEYH-15 & 1440 & 617 & 1029 \\
10 & EEYH-16 & 2983 & 765 & 1874 \\
11 & EEYH-17 & 3271 & 753 & 2012 \\
12 & EEYH-18 & 3093 & 336 & 1714 \\
13 & EEYH-19 & 3180 & 587 & 1884 \\
14 & EEYH-20 & 1919 & 579 & 1249 \\
15 & EEYH-21 & 3174 & 292 & 1733 \\
16 & EEYH-23 & 1997 & 422 & 1209 \\
17 & EEYH-24 & 1340 & 422 & 881 \\
18 & EEYH-25 & 2748 & 853 & 1800 \\
19 & EEYH-26 & 3143 & 560 & 1852 \\
20 & EEYH-27 & 3420 & 808 & 2114 \\
21 & EEYH-28 & 3484 & 646 & 2065 \\
22 & EEYH-29 & 3165 & 484 & 1824 \\
23 & EEYH-30 & 1368 & 556 & 962 \\
24 & EEYH-32 & 1842 & 741 & 1291 \\
\hline & LSDa0.05 & 1207 & 708 & \\
\hline
\end{tabular}


Table 6: Correlation coefficients between grain yield and related traits in maize hybrids of two maturity groups (Ilorin, Nigeria).

\begin{tabular}{lcccc}
\hline & \multicolumn{2}{c}{ Early white QPM Hybrids } & \multicolumn{2}{c}{ Extra-early Yellow Hybrids } \\
\cline { 2 - 5 } Trait & 2012 & 2013 & 2012 & 2013 \\
\hline Days to silking & -0.303 & -0.223 & 0.084 & -0.039 \\
Anthesis silking interval & 0.285 & $-0.365^{\star}$ & 0.037 & -0.113 \\
Plant height & $0.449^{\star *}$ & $0.448^{\star *}$ & $0.364^{*}$ & 0.146 \\
Ears per plant & $0.698^{\star *}$ & $0.611^{\star *}$ & $0.897^{\star *}$ & $0.475^{\star *}$ \\
\hline
\end{tabular}

*, **; Significant $r$ values at 0.05 and 0.01 levels of probability respectively

Table 7: Regression statistics for grain yield $(y)$ relative to related traits $(x)$ in two maize hybrids of different maturity (llorin, Nigeria).

\begin{tabular}{lllll}
\hline Trait & Regression Equation & R2 & R & Probability \\
\hline \multicolumn{5}{c}{ Early white QPM Hybrids } \\
\hline Anthesis-silking-interval & $y=14.638 x+2007.1$ & 0.0013 & 0.036 & $0.889 \mathrm{~ns}$ \\
Plant Height & $\mathrm{y}=33.412 x-1592.6$ & 0.2551 & 0.505 & 0.039 \\
Ears per plant & $y=6720.9 x+271.45$ & 0.1937 & 0.440 & 0.077 \\
\hline \multicolumn{5}{c}{ Extra-Early Yellow Hybrids } \\
\hline Anthesis-silking-interval & $y=235.09 x+942.49$ & 0.0836 & 0.289 & $0.171 \mathrm{~ns}$ \\
Plant Height & $y=-3.8029 x+2131.9$ & 0.0014 & 0.037 & $0.860 \mathrm{~ns}$ \\
Ears per plant & $y=1823.4 x-319.43$ & 0.7572 & 0.870 & 0.000 \\
\hline
\end{tabular}

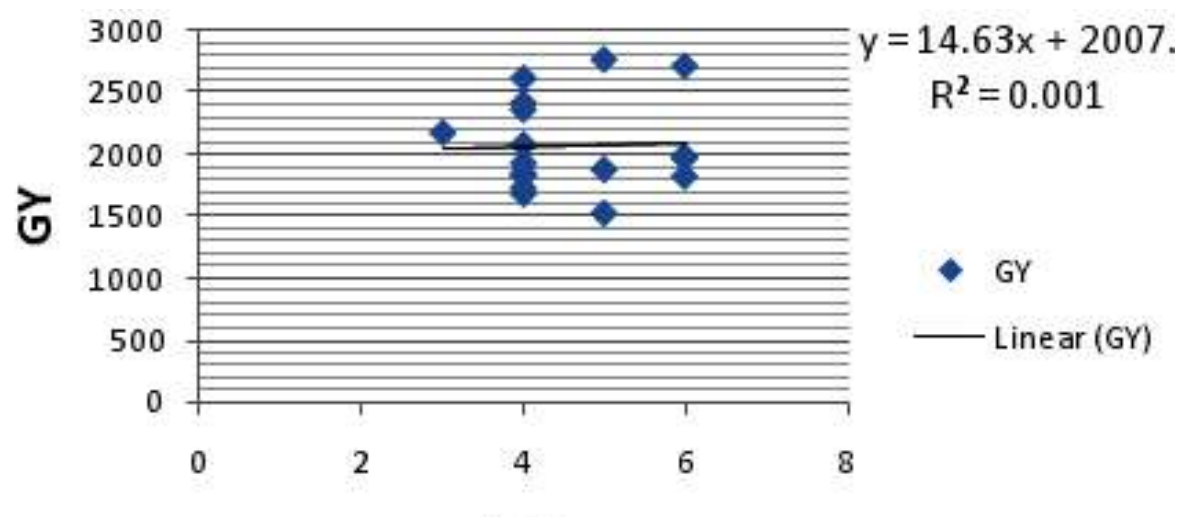

ASI

Fig 1a: Scatter plot of grain yield against anthesis silking interval in 17 early white QPM hybrids. 


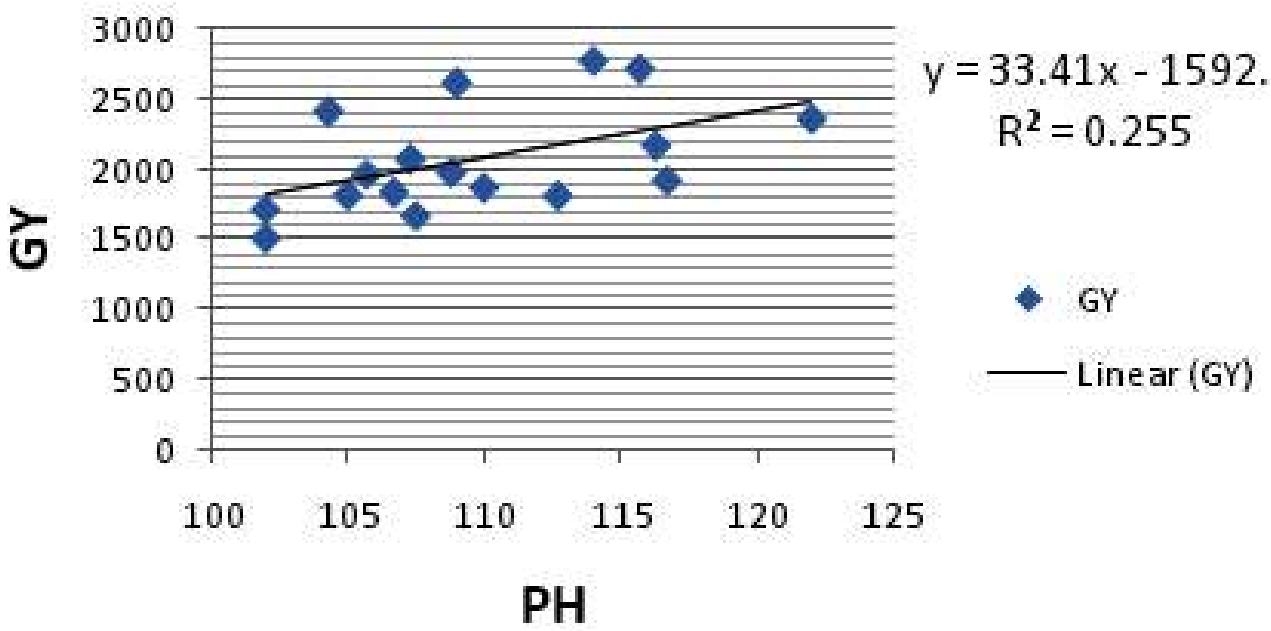

Fig 1b: Scatter plot of grain yield against plant height in 17 early white QPM hybrids.

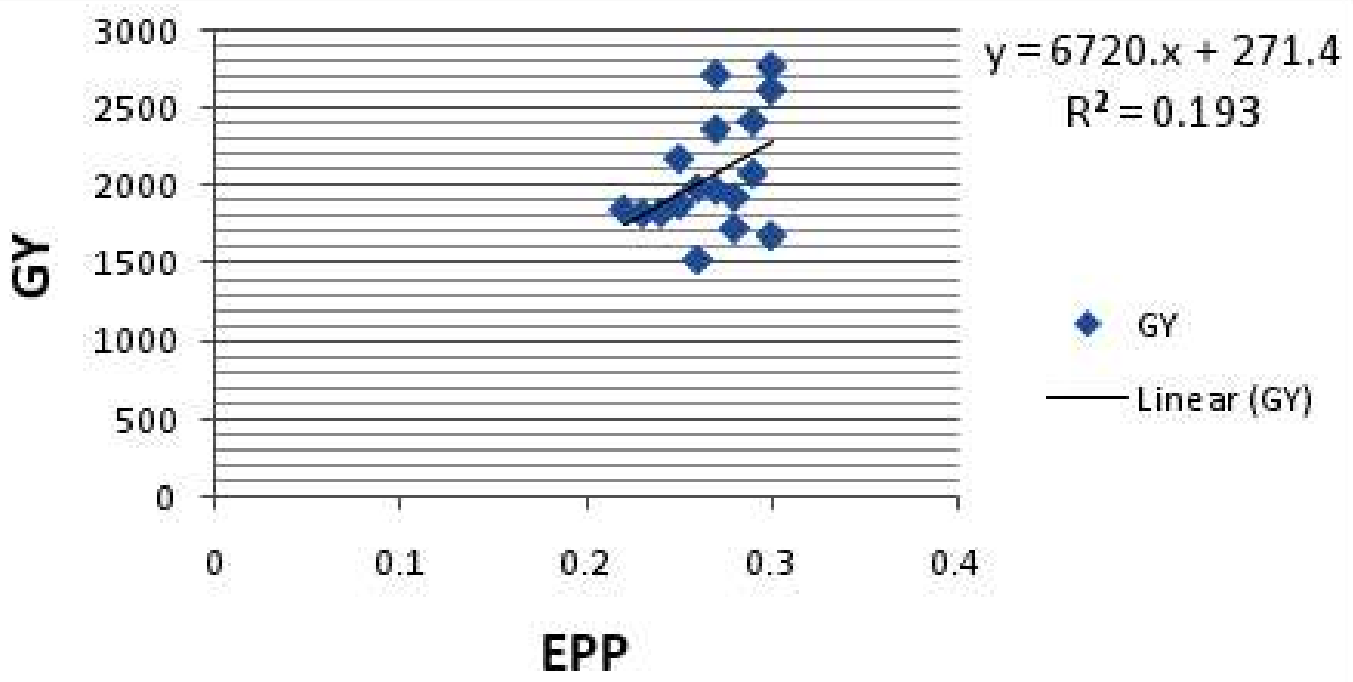

Fig 1c: Scatter plot of grain yield against ears per plant in 17 early white QPM hybrids. 


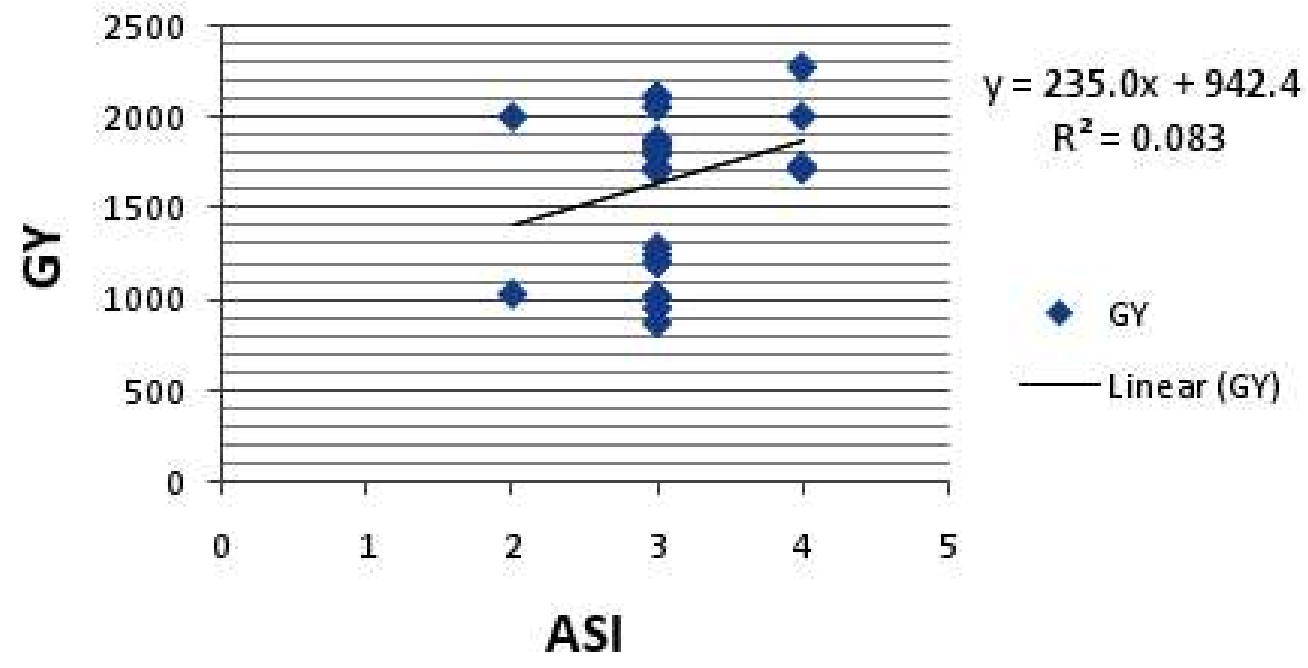

Fig 2a: Scatter plot of grain yield against anthesis silking interval in 24 Extra-early Yellow Hybrids

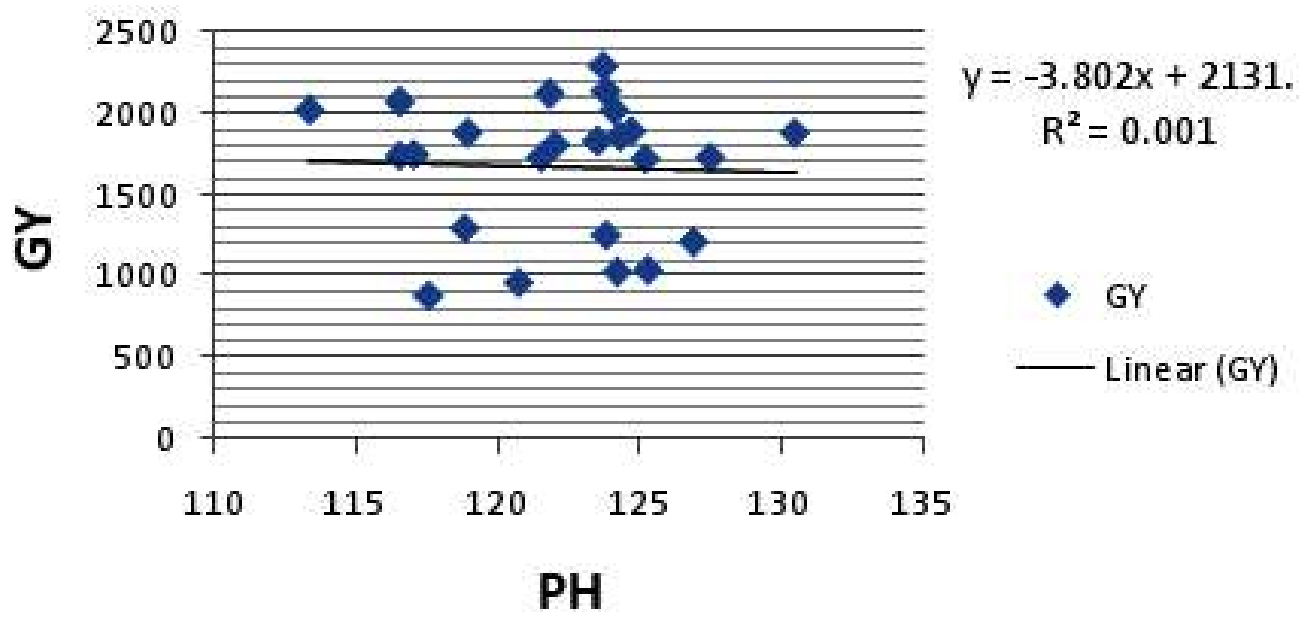

Fig 2b: Scatter plot of grain yield against plant height in 24 Extra-early Yellow Hybrids 


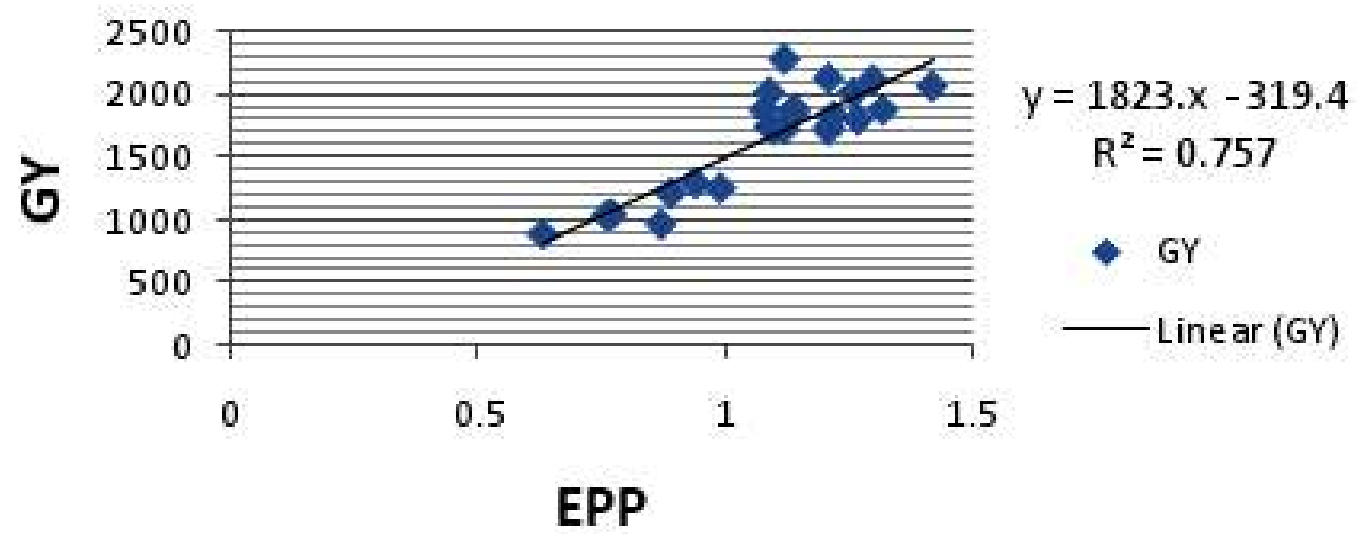

Fig 2c: Scatter plot of grain yield against ears per plant in 24 Extra-early Yellow Hybrids 